\title{
Application of Continuous Wavelet Transform to Layer Boundaries Detection from Gamma Ray Log
}

\author{
Arya Dwi Candra ${ }^{1, *}$ Bambang Yudho Suranta ${ }^{1}$ Sulistiyono $^{1}$ Nur L Maulidiyah ${ }^{2}$
}

\author{
Andri Syafriya ${ }^{3}$ Dessy Widya ${ }^{3}$ Sungkono $^{2}$
}

\author{
${ }^{1}$ Oil and Gas Production Engineering Department, Politeknik Energi dan Mineral Akamigas, 58315, Indonesia \\ ${ }^{2}$ Department of Physics, Faculty of Science and Data Analytics, Institut Teknologi Sepuluh Nopember, 60111, \\ Indonesia \\ ${ }^{3}$ PetroChina International Jabung Ltd., Jakarta, Indonesia. \\ *Corresponding author. Email: aryadcandra@gmail.com
}

\begin{abstract}
Layer boundary analysis is an important process in determining the net pay value. Although the layer boundary can be determined manually through mud log data, it can also be determined automatically by signal analysis using wavelet transform. This analysis uses the gamma ray (GR) log data and the resistivity log. The type of wavelet used is Continuous Wavelet Transform (CWT). The CWT workflow begins with a blocking trace process to find inflection points in the GR $\log$ data and the resistivity log based on derivative analysis by convoluting the signal with the wavelet operator that matches the original frequency. Several parameters are required as input of the wavelet transform method such as number of layers detected and minimum thickness requirements which are 3 and 1 . As for the input, the percentage of layer extract varies from $25 \%, 30 \%$ and $35 \%$. The result of the comparison of layer boundaries from mud log data with CWT has the lowest difference in the yield of layer extract $35 \%$. Where the results of the layer boundary on the mud $\log$ data on NP 1, NP 2, P 1, P 2 and P 3 wells are 155, 248, 29, 10 and 343, respectively, while the results of the bed boundary with 35\% layers extract at NP 1, NP 2, P 1, P 2 and P 3 wells are 168, 192, 30, 11 and 312 layers, respectively. The big difference of layer number identification in the NP1, NP2 and P3 is presumably because the CWT algorithm does not involve thin layer analysis (less than $1 \mathrm{ft}$ ).
\end{abstract}

Keywords: Layer boundary, Continuous Wavelet Transform, Log Gamma Ray, Mud Log, Talang Akar Formation, South Sumatra Basin.

\section{INTRODUCTION}

Knowing the important role of petroleum, exploration and production activities of petroleum must be carried out. Before carrying out production activities, the developer first needs to understand and make careful planning regarding potential and economic fields to be used as a source of oil and gas. One of the means of understanding is knowing the reserve value of the well. To determine reserves, several petrophysical parameters are needed, one of which is the net pay. Net pay is the thickness of the productive zone on a reservoir which is used to calculate volumetric reserves [1].
In this study, the net pay zone was analyzed in the Talang Akar Formation in the South Sumatra Basin. This is because in the Talang Akar Formation, the majority of the constituent rocks are sandstone and shaly sand so that it is easier to analyze when compared to other formations in the same basin (South Sumatra) [2]. According to Bishop et al. [3] mostly rock composition at the Talang Akar Formation is sandstone, so that this formation is the largest with an estimated reservoir containing $75 \%$ of oil production from all over the South Sumatra Basin.

Generally, the reservoir is placed to sedimentary rocks because they have a greater porosity than igneous or metamorphic. Reservoir is one of the components in 
the petroleum system besides source rock, seal, trap, and migration route [3]. In the reservoir (Talang Akar Formation) "productive" rocks are further divided into several layers based on the composition of rock types (lithology) so that further analysis is necessary in regards those layer boundaries in the Talang Akar Formation.

The determination of layer boundaries was initially investigated using mud log data by calculating (manually) the difference in lithology based on the colour differences recorded in the mud log data record. Calculation using manual method causes the determination of layer boundaries to be longer and requires a lot of human resources. To overcome this problem, we need a method that can determine layer boundaries automatically. A significant number of signal analysis methods have been applied to geophysical methods, including the EMD method to decrease noise in seismic data [4], [5], figuring out high-frequency sedimentary cycles of oil source rocks [6], determining reservoir anomalies from pressure transient data [7], [8], as well as for characteristic extraction in well-log data [9]. Vega [9] utilized pattern recognition technique to be determined the top of formation, and investigated stratigraphic correlation of the wells.

Wavelet analysis has been one of the most powerful mathematical tools for assisting a comprehensive understanding of composite signals like well-logs. Compared to traditional correlations using visual inspection of well-logs, all these methods have been shown to be helpful for better understanding of subsurface layers. This research is the development of concepts that were previously done by Davis and Christensen [10] to analyze the boundary layer. In this study, identification of layer boundaries was carried out automatically using signal analysis, namely wavelet transformations on the Gamma Ray (GR) log and resistivity (LLD) $\log$ data. Analysis focused on the reservoir boundary layer that is located on Talang Akar Formation South Sumatra Basin by using CWT.

\section{CWT}

Wavelet transformation is a signal processing method used to simultaneously analyze a signal in the frequency and time or space domains [11]. This study uses one type of wavelet transform, namely Continuous Wavelet Transform (CWT). CWT is applied to petrophysical data by analogizing depth (ft) as the time domain and formation (layer boundary) as the frequency domain. CWT uses a windowing technique where the radius increases in space, the frequency will decrease and vice versa. Wavelet transform can be defined by Equation 1 .

$$
W_{\psi} f(a, b)=\frac{1}{\sqrt{a}} \int_{-\infty}^{\infty} f(t) \psi *\left(\frac{t-b}{a}\right) d t, \quad, \quad{ }_{-\infty}
$$

Where $\psi^{*}$ is the conjugate complex of $\psi$. The parameters $a$ and $b$ respectively denote the dilation and translation parameters. At all $a$ scales, the wavelet coefficient $W_{\psi a, b}$ is generated by convoluting $f(t)$ and wavelet in parameters $a$ dan $b$.

Based on the research of Vega [9], the best wavelet for layer boundary identification is the Morlet wavelet which is the second derivative of the Gaussian Equation. This transformation works to find the wavelet coefficient that is most similar to the original frequency while also providing the best resolution

\section{METHOD}

This study uses log data for five wells, namely NP 1 , NP 2, P 1, P 2 and P 3 in the "P" field which consists of a gamma ray (GR) $\log$ and a resistivity $\log (\mathrm{LLD})$. There is also a mud log containing information on lithology data that was acquired during drilling. The wavelet transform workflow in this study begins with the blocking trace process where the search for the data inflection point of the gamma ray $\log$ and the resistivity $\log$ is used to determine the layer boundary using a linear approach algorithm based on derivative analysis. CWT analysis works by convoluting the signal with the wavelet operator according to the following equation:

$X_{e} * W=f^{-1}\left(f\left(X_{e}\right) \circ f(W)\right)$

Where $X_{e}$ indicates the newly formed trace matrix and $\boldsymbol{W}$ denotes the wavelet matrix. After the algorithm is formed, the next step is to detect the layer boundary with $\log$ GR as shown in Figure 2 (a). The blue colour shows negative deflection, the red colour shows positive deflection and the black line is the cross over area between blue and red which indicates an inflection at that depth [10]. Figure 1 (b) shows CWT result using derivative analysis to extract $35 \%$ of the layer. The boundaries between layers in a formation are shown in green. The data output generated from this analysis is the upper and lower limits of each layer and the thickness of each layer in the Talang Akar Formation. 


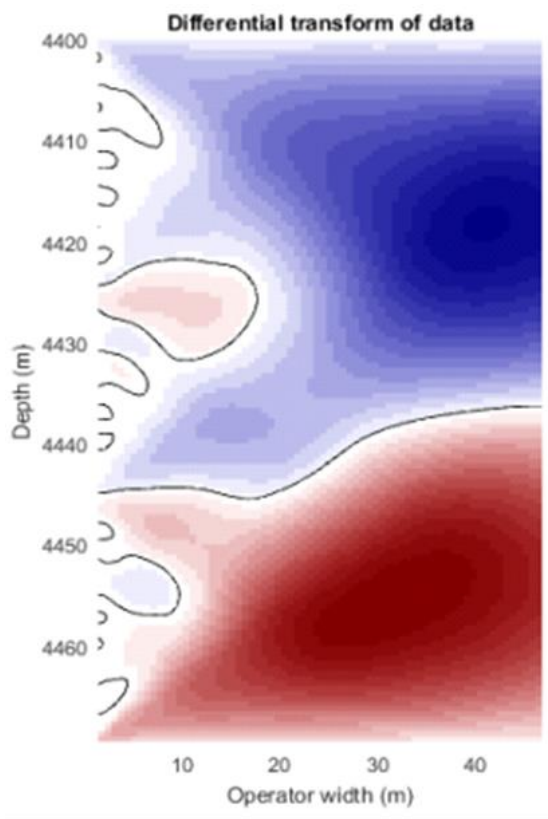

(a)

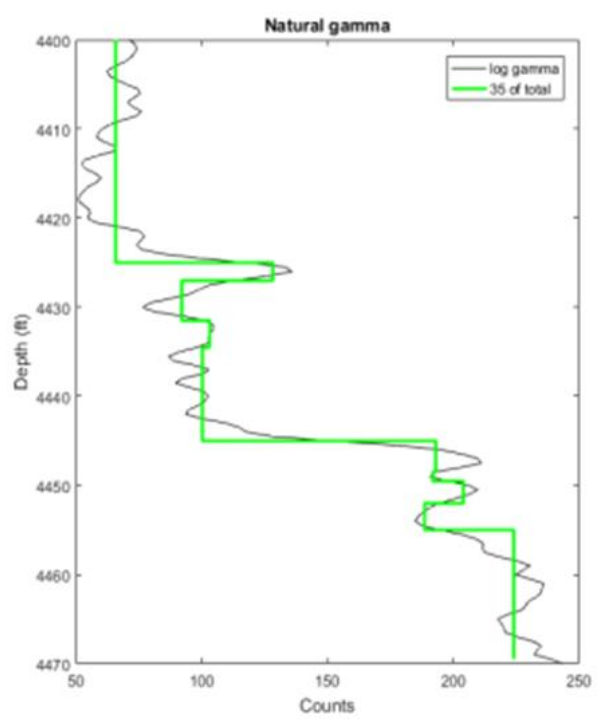

(b)

Figure 1 The cross over zone from negative deflection (blue) and positive deflection (red) in GR log (a), and plot GR $\log$ (black curve) which is overlying with 35\%-layer boundary extraction (green curve) (b).

Furthermore, qualitative analysis was carried out on the GR log data by looking at the patterns and features of each zone to determine the position of the Talang Akar Formation. Then the quantitative analysis is carried out by counting the number of layers in the mud log data and comparing it with the results of the number of layers in the wavelet transform.

\section{RESULT AND DISCUSSION}

\subsection{Multi Well Log Gamma Ray Correlation}
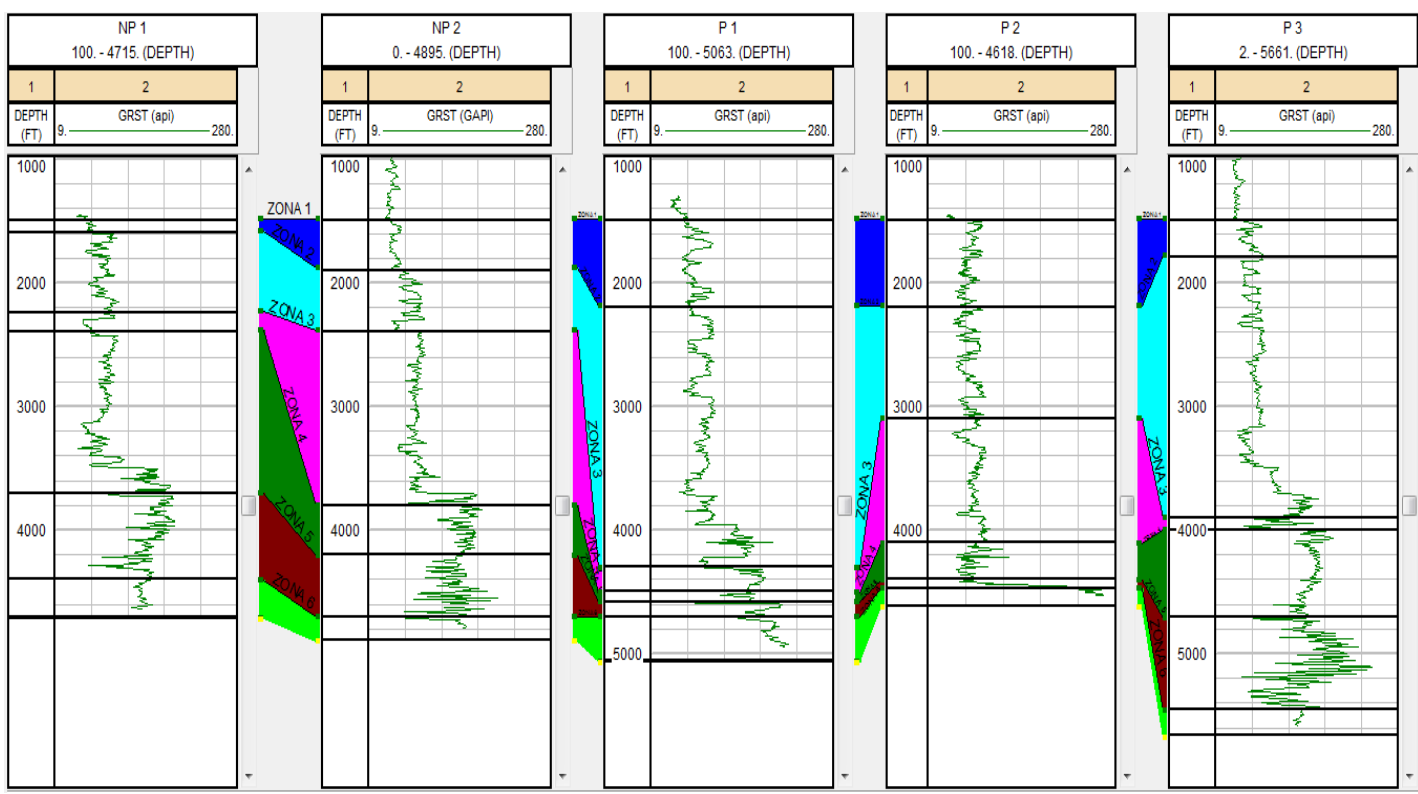

Figure 2 Comparison of the results of the number of layers between the mud log data and the extract of $25 \%, 30 \%$ and $35 \%$ layers.
Determination of top depth and bottom depth limits in the Talang Akar Formation is carried out through qualitative analysis through correlation on $\log$ GR (Figure 2). According to the North American Stratigraphy Code [12], there are three kinds of correlation, namely litho correlation, bio correlation and chrono correlation. In this study, litho correlation is used by connecting the same units in the lithology and its stratigraphic position. The lithology and stratigraphic information can be validated by well report. 
The Litho correlation process is carried out by equating the datum (flatten). Datum is a similarity data that belongs to all wells to be correlated to the depth (depth). Figure 2 indicates that the datum used is located at a depth of $1500 \mathrm{ft}$ because starting from that depth, all wells are available with GR log data.

All wells are divided into six zones and correlated with subsequent wells in sequence. Boundaries at NP 1 well are correlated with NP 2 well, NP 2 well correlated with $\mathrm{P} 1$ well, and so on. The boundaries in question are Zone 1 to Zone 6 in Figure 2 which is obtained from the key horizon tops on the well report. Figure 2 shows that significant changes in GR log can be seen in zone 4 and zone 5 . The change in question is that GR log is recorded as getting bigger, so that the zone can be categorized as a reservoir zone. the upper and lower boundary of the Talang Akar Formation at NP 1, NP 2, P 1, P 2 and P 3 wells can be seen in Table 1 .

Table 1. Top and bottom depth of the Talang Akar Formation based on litho correlation.

\begin{tabular}{|l|l|l|l|l|}
\hline \multirow{2}{*}{ Well } & \multicolumn{2}{|l|}{ Upper Talang Akar } & \multicolumn{2}{l|}{ Lower Talang Akar } \\
\cline { 2 - 5 } & Top & Bottom & Top & Bottom \\
\hline NP 1 & 3700 & 4400 & 4400 & 4700 \\
\hline NP 2 & 3800 & 4200 & 4200 & 4700 \\
\hline P 1 & 4500 & 4580 & 4580 & 4700 \\
\hline P 2 & - & - & 4400 & 4470 \\
\hline P 3 & 4000 & 4700 & 4700 & 5450 \\
\hline
\end{tabular}

Based on mud log data, all wells in the "P" Field, in general the difference between Upper and Lower Talang Akar lies in the constituent lithology. The percentage of rocks containing shale and carbonate (such as claystone and siltstone) in Upper Talang Akar is greater than that of lower Talang Akar, which is dominated by sandstone [13]. Furthermore, Table 1 shows that well P 2 does not have upper Talang Akar. This is due to the unconformity that occurs in the "P" Field, so that not all wells contain the same rock formations. Unconformity is the discontinuation of rock layers caused by various factors, one of which is due to different settling time lags so that the depositional environment is also different [13].

\subsection{CWT analysis}

After knowing the upper and lower limits of the Talang Akar Formation in each well from the correlation results in the previous discussion, a CWT analysis was carried out to determine the number of layers in the Talang Akar Formation. Initially, the determination of layer boundaries was carried out by means of correlation to drilling data, namely core data and mud log. Drilling data used is mud log data due to the limited core data available. Mud log data is drilling data obtained from cutting rocks that are carried to the surface when mud circulates from depth to surface. The function of the mud $\log$ is to describe the cutting rocks and knowing lithology, the estimated values of porosity and permeability, and estimation of pore pressure. However, mud log data has several limitations, for example when the type of mud used in the drilling process is clay rich content, so that the log reading is less than optimal and drilling data is sometimes only acquired every meter or half meter so that information may be lost during the drilling process [10].

Well $\log$ data is also used in determining layer boundaries in addition to drilling data. If drilling data is obtained at the same time as the drilling process, well log data is acquired when the drilling of holes in the well is completed. Logging tools are derived to record data continuously, for example the recorded data is a Gamma ray log. Just like mud logs, well log data also has several limitations, for example, there is noise in the measurement results which causes limited resolution so that the determination of layer boundaries is less accurate [10].

Determination of the layering system was carried out based on gamma ray log data using the CWT method developed by Davis and Christensen [10]. In CWT derivative analysis, there are several functions available to determine layer boundaries based on several parameters, including: the minimum detected layer thickness, the absolute number of layers and the percentage of layers relative to the total number of layers detected). In this research, blocking trace method is used with a relative percentage of the total layers. This method was chosen because the computation process is relatively fast with simple modeling [10]. 


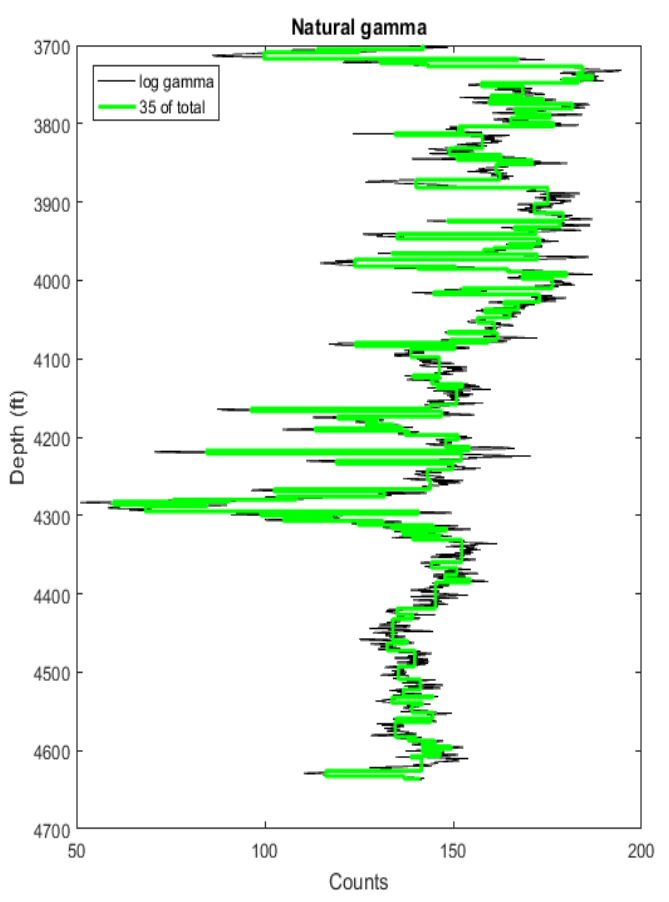

(a)

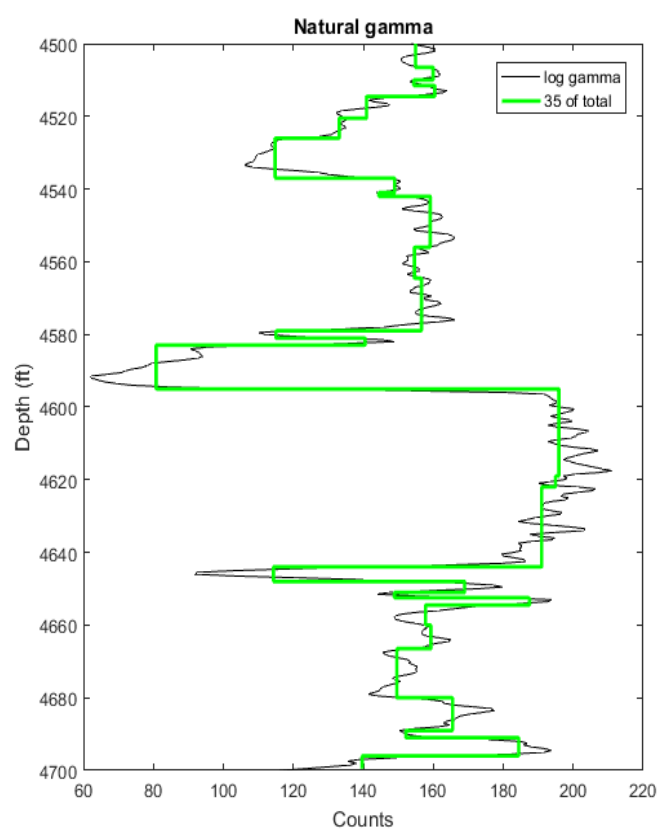

(c)

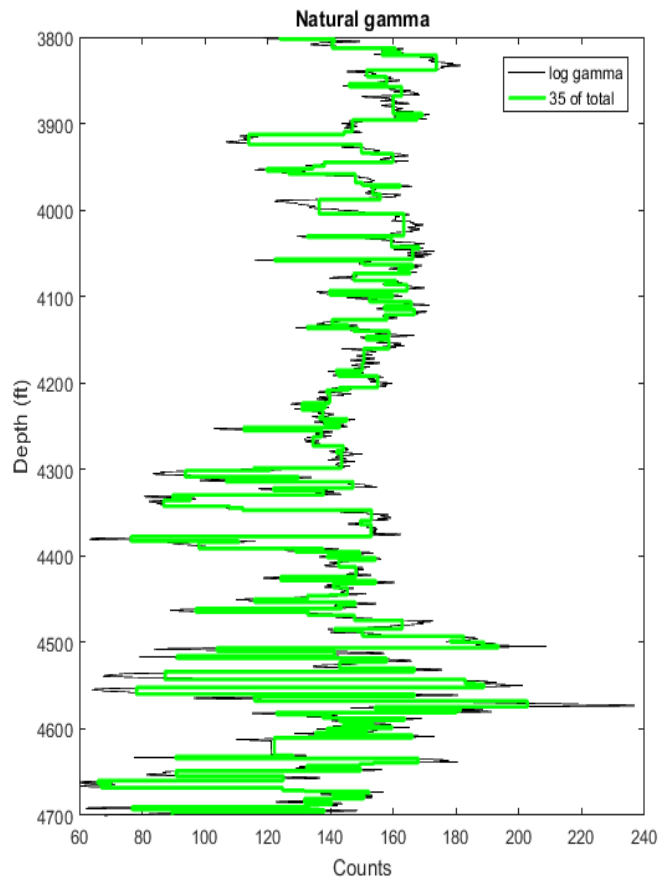

(b)

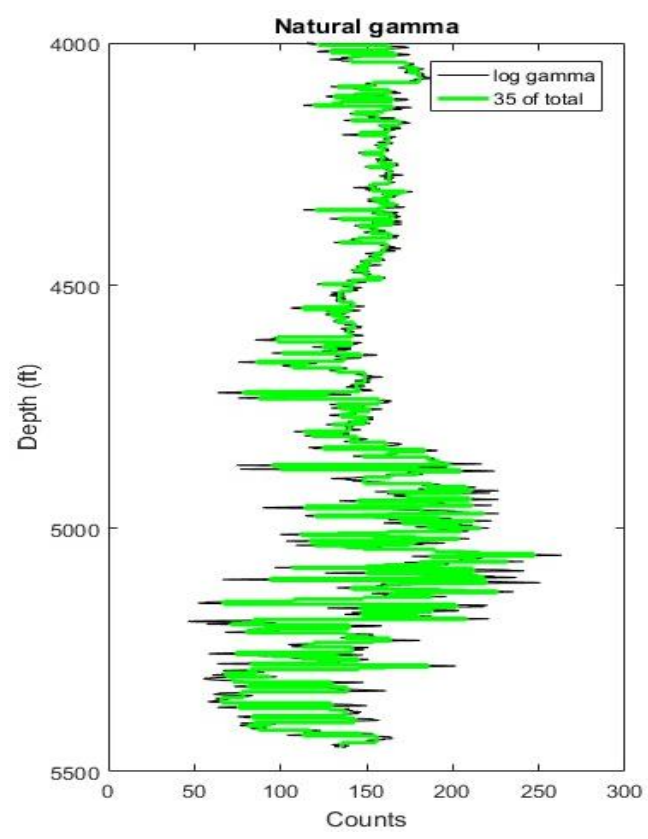

(d)

Figure 3 Gamma Ray (GR) log plots with 35\%-layer extraction results using CWT analysis on wells NP 1, NP 2, P 1 and $\mathrm{P} 3$ are shown in Figure (a), (b), (c) and (d), respectively.

To process this wavelet, transform algorithm, several input operators are required, namely: number of layers detected, percentage of layer extract, and minimum thickness requirements. In this study, the value of number of layers detected and the minimum thickness requirements were set as 3 and 1, while the percentage value of layer extract was varied from $25 \%, 30 \%$, and $35 \%$. Furthermore, the number of layers detected using the CWT method was compared with the results of mud $\log$ analysis.

The resulting layer from log GR with 35\%-layer extract that is "overlying" above the GR $\log$ at Well P 2 and other wells can be seen in Figure 3. This figure shows that CWT analysis with this parameter can be used to predict the layer from the GR $\log$. The GR $\log$ was selected in this analysis because of the fast and accurate 
nature of the GR $\log$ in identifying differences in rock lithology compared to other logs.

Figure 4 shows the difference in the number of layer boundaries from the CWT analysis (variation in the percentage of layer extract) with manual calculations on the mud log data. This figure shows that the number of layers determined from the parameter of 35\% layers extract percentage is closer to the number of layers from the mud log analysis. Furthermore, Figure 4 shows that the most significant difference in the number of layers is in the NP 2 well, which has a difference between the results of the CWT analysis and the mud log is 56 layers. This is thought to be caused by the NP 2 well there are many thin layers (the difference in lithology is thin or the distance from one lithology to another is very small/thickness is less than $1 \mathrm{ft}$. These thin layers, in CWT can be considered as noise.

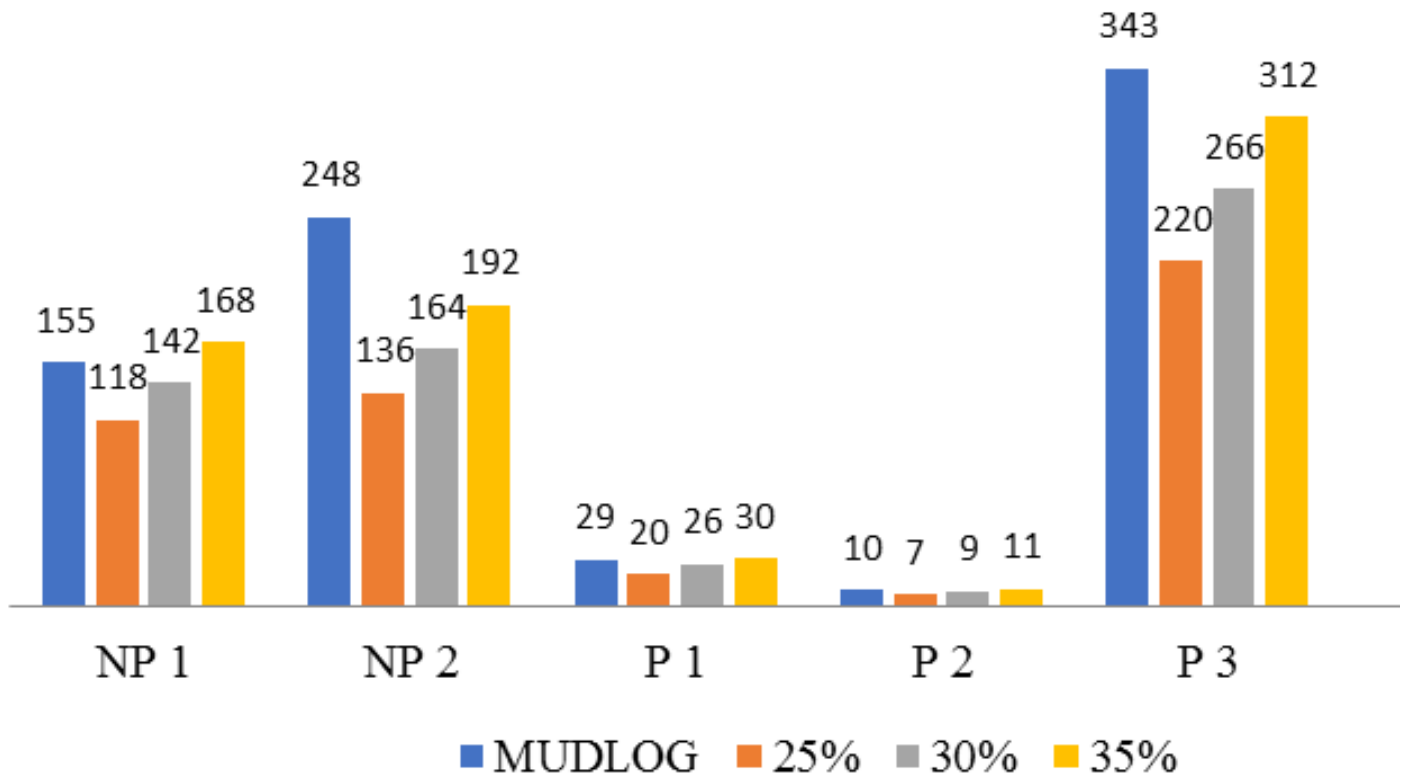

Figure 4 Comparison of the results of the number of layers between the mud log data and the extract of $25 \%, 30 \%$ and $35 \%$ layers.

\section{CONCLUSION}

The comparison result of layer boundaries from mud $\log$ data with CWT analysis has the lowest difference in the yield of $35 \%$ layers extract. Boundary layer of Talang Akar Formation was analyzed using CWT method produces accurate boundary layer. The number of layers in wells NP 1, NP 2, P 1, P 2 and P 3 are 168, 192, 30, 11 and 312 respectively. The biggest difference is in the NP 2 Well, because the CWT method does not involve thin layer analysis (less than $1 \mathrm{ft}$ ).

\section{ACKNOWLEDGMENT}

This research was supported by Politeknik Energi dan Mineral Akamigas, Ministry of Energy and Mineral Resources of the Republic of Indonesia. The Well Log Data used in the present study were provide by Pusdatin ESDM. We are very grateful to an anonymous reviewer for their useful comments and suggestions.

\section{REFERENCES}

[1] P. F. Worthington, "Net Pay--What Is It? What Does It Do? How Do We Quantify It? How Do We
Use It?," SPE Reserv. Eval. Eng., vol. 13, no. 05, Art. no. 05, Oct. 2010, doi: 10.2118/123561-PA.

[2] D. Ginger and K. Fielding, "The Petroleum Systems and Future Potential of the South Sumatra Basin," 2005, doi: 10.29118/ipa.2226.05.g.039.

[3] M. G. Bishop, "South Sumatra Basin Province, Indonesia; the Lahat/Talang Akar-Cenozoic total petroleum system,” 2000, doi: 10.3133/OFR9950S.

[4] A. D. Candra and P. E. Suryani, "Application of Multivariate Empirical Mode Decomposition to Noise Reduction in Seismic Signal," J. Phys. Conf. Ser., vol. 1204, p. 012004, Apr. 2019, doi: 10.1088/1742-6596/1204/1/012004.

[5] A. D. Candra and P. E. Suryani, "Perbandingan Metode EEMD dan EMD untuk Mereduksi Noise pada Sinyal Seismik," J. Ilm. Teknosains, vol. 4, no. 1, Art. no. 1, Jun. 2018, doi: 10.26877/jitek.v4i1.1814.

[6] A. Prokoph and F. P. Agterberg, "Wavelet analysis of well-logging data from oil source rock, Egret Member, offshore eastern Canada," AAPG Bull., vol. 84, no. 10, Art. no. 10, 2000. 
[7] M. N. Panda, C. C. Mosher, and A. K. Chopra, "Application of Wavelet Transforms to ReservoirData Analysis and Scaling," SPE J., vol. 5, no. 01, Art. no. 01, Mar. 2000, doi: 10.2118/60845-PA.

[8] M. Y. Soliman, J. Ansah, S. Stephenson, and B. Mandal, "Application of Wavelet Transform to Analysis of Pressure Transient Data," presented at the SPE Annual Technical Conference and Exhibition, Jan. 2001, doi: 10.2118/71571-MS.

[9] N. Rivera Vega, Reservoir characterization using wavelet transforms. Texas A\&M University, 2004.

[10] A. C. Davis and N. B. Christensen, "Derivative analysis for layer selection of geophysical borehole logs," Comput. Geosci., vol. 60, pp. 34-40, Oct. 2013, doi: 10.1016/j.cageo.2013.06.015.
[11] F. J. Herrmann, "A scaling medium representation: A discussion on well-logs, fractals and waves," 1997, Accessed: Feb. 17, 2020. [Online]. Available: https://repository.tudelft.nl/islandora/object/uuid\% 3A5423a23f-814e-4260-ba9b-f60e16cd2f14.

[12] The North American Commission on Stratigraphic Nomenclature, "North American Stratigraphic Code," Nov. 28, 2020. https://ngmdb.usgs.gov/Info/NACSN/Code2/code2 .html (accessed Nov. 28, 2020).

[13] G. Coster, "The Geology of the Central and South Sumatra Basins," presented at the 3rd Convention Proceedings, 1974. 